\title{
EFEKTIVITAS ARANG SEKAM PADI DALAM MENURUNKAN KADAR BESI (Fe) PADA AIR SUMUR BOR DI DESA PADANGLOANG KABUPATEN PINRANG
}

\author{
Effectiveness Of Rice Husk Charcoal In Reducing Iron (Fe) Levels In Well Water Of Borrow In \\ Padangloang Village Pinrang Regency \\ Riskawati, Rahmi Amir, Herlina Muin \\ (Program Studi Kesehatan Masyarakat Fakultas Ilmu Kesehatan Universitas Muhammadiyah \\ Parepare) \\ (riskasyahrul250@gmail.com)
}

\begin{abstract}
ABSTRAK
Kadar besi $(\mathrm{Fe})$ yang melebihi ambang batas dapat menimbulkan dampak negatif terhadap air antara lain kondisi air berwarna kuning, berasa dan bau besi atau karat. Sedangkan efek negatif pada kesehatan manusia adalah dapat menggangu sistem reproduksi dan berpotensi sebagai pemicu kanker apabila dikomsumsi dalam kurun waktu lama. Tujuan penelitian ini adalah untuk mengetahui efektifitas arang sekam padi dalam menurunkan kadar besi $(\mathrm{Fe})$ pada Sumur Bor di Dusun Banga Desa Padangloang Kabupaten Pinrang, Jenis penelitian ini adalah quasy eksperimen dimana setiap perlakuan dilakukan pengulangan sebanyak 3 kali. Hasil pada penelitian ini yaitu kadar besi (Fe) sebelum perlakuan sebanyak $1,81 \mathrm{mg} / \mathrm{l}$ dan setelah perlakuan penambahan arang sekam padi dengan konsentrasi yang berbeda terjadi penurunan kadar besi $(\mathrm{Fe})$ pada Sumur Bor di Dusun Banga Desa Padangloang Kabupaten Pinrang. Dari konsentrasi 5 gram, 10 gram, dan 15 gram yang paling efektif untuk menurunkan kadar besi (Fe) adalah 15 gram dengan $100 \mathrm{ml}$ air, hasil yang didapatkan $0,30 \mathrm{mg} / \mathrm{l}$. Semakin banyak jumlah konsentrasi arang sekam padi maka semakin tinggi tingkat penurunan kadar besi $(\mathrm{Fe})$. Arang sekam padi dapat dikatakan efektif dalam menurunkan kadar besi $(\mathrm{Fe})$ pada air sumur bor di Dusun Banga Desa Padangloang Kabupaten Pinrang sesuai dengan peraturan yang telah ditetapkan oleh Peraturan Menteri Kesehatan RI Nomor 492/Menkes/Per/IV/2010 tentang persyaratan kualitas air bersih.
\end{abstract}

Kata Kunci: Arang pekam padi, kadar besi (Fe), air sumur bor

\begin{abstract}
Iron (Fe) levels that exceed the threshold can cause negative impacts on water, including yellow water conditions, taste and smell of iron or rust. While the negative effects on human health are able to interfere with the reproductive system and have the potential to trigger cancer if consumed for a long time. The purpose of this study was to determine the effectiveness of rice husk charcoal in reducing iron ( $\mathrm{Fe}$ ) levels in Drilling Well in Banga Hamlet, Padangloang Village, Pinrang Regency. This type of research was an experimental quasy where each treatment was repeated three times.

The results of this study were levels of iron ( $\mathrm{Fe}$ ) before treatment as much as $1.81 \mathrm{mg} / \mathrm{l}$ and after treatment of adding rice husk charcoal with different concentrations there was a decrease in iron
\end{abstract}


(Fe) levels in the Drilling Well in Banga Hamlet, Padangloang Village, Pinrang Regency. From the concentration of 5 grams, 10 grams, and 15 grams, the most effective for reducing iron ( $\mathrm{Fe}$ ) is 15 grams with $100 \mathrm{ml}$ of water, the results obtained are $0.30 \mathrm{mg} / \mathrm{l}$. The more the amount of rice husk charcoal concentration, the higher the level of iron $(\mathrm{Fe})$ decrease. Rice husk charcoal can be said to be effective in reducing iron content in borehole water in Banga Hamlet, Padangloang Village, Pinrang Regency in accordance with the regulations stipulated by the Republic of Indonesia Minister of Health Regulation No. 492 / Menkes / Per / IV / 2010 concerning requirements for clean water quality.

Keywords: Rice husk charcoal, Iron (Fe) Level, Water Well 


\section{PENDAHULUAN}

Air merupakan zat yang paling penting dalam kehidupan setelah udara. Sekitar tiga per empat bagian dari tubuh kita terdiri dari air dan tidak seorang pun dapat bertahan hidup lebih dari empat sampai lima hari tanpa minum air. Air juga merupakan sumber daya alam yang diperlukan untuk hajat hidup orang banyak, bahkan untuk semua makhluk hidup. ${ }^{1}$

Ditinjau dari sudut ilmu kesehatan masyarakat, penyediaan sumber air bersih harus dapat memenuhi kebutuhan masyarakat karena persediaan air bersih yang terbatas memudahkan timbulnya penyakit di masyarakat.Volume rata-rata kebutuhan air setiap individu per hari berkisar antara 150-200 liter atau 34-40 galon. Kebutuhan air tersebut bervariasi dan bergantung pada keadaan iklim, standar kehidupan dan kebiasaan masyarakat. ${ }^{2}$ Menurut Margono (2010) Kadar besi $(\mathrm{Fe})$ dalam air dapat diturunkan dengan menggunakan karbon aktif sebagai media saring. Karbon aktif adalah sejenis absorben (penyerap). Berwarna hitam, berbentuk granula, bulat, pelet atau bubuk. Arang bisa digunakan untuk menghilangkan bau dan warna pada air. Arang merupakan suatu padatan berpori yang mengandung 85-95\% karbon, dihasilkan dari bahan-bahan yang mengandung karbon dengan pemanasan pada suhu tinggi. Karbon aktif dapat dipergunakan dengan cara menaburkan, dicampur air lalu dibubuhkan, dipasang sebagai filter dan sebagainya. Arang aktif sangat efektif untuk menghilangkan warna, bau dan rasa dalam air. ${ }^{3}$

Berdasarkan pengamatan bahwa air sumur bor yang ada di Dusun Banga Desa Padang Loang Kecamatan Patampanua Kabupaten Pinrang mengandung kadar besi $(\mathrm{Fe})$ karena air berbau besi dan lama kelamaan lantai kamar mandi berkerak. Berdasarkan Permenkes RI No

492/MENKES/PER/IV/2010 tentang persyaratan kualitas air bersih yang menerangkan bahwa kadar besi dalam air maksimum diperbolehkan 1,0 mg/l. ${ }^{4}$

Kelebihan zat besi bisa menyebabkan keracunan dimana terjadi muntah, kerusakan usus, penuaan dini hingga kematian mendadak, mudah marah, cacar lahir, gusi berdarah, kanker, sirosis ginjal, sembelit, diabetes, diare, pusing, mudah lelah, kulit kehitam-hitaman, sakit kepala, gagal hati, hepatitis, mudah emosi, hiperaktif, hipertensi, infeksi, insomnia, sakit liver, masalah mental, rasa logam di mulut, mudah gelisah dan iritasi, rematik, keras kepala, gangguan penyerapan vitamin dan mineral.

Oleh karena itu peneliti tertarik untuk mengembangkan penggunaan arang sekam padi dalam menurunkan kadar besi (Fe) pada air sumur bor. Pemilihan sekam padi sendiri disebabkan karena selama ini sekam padi hanya menjadi limbah yang belum dimanfaatkan secara optimal. 
Sekam padi lebih sering digunakan sebagai bahan pembakar bata merah, abu gosok atau dibuang begitu saja. Padahal limbah ini bisa dimanfaatkan sebagai arang aktif yang akan lebih berguna bagi masyarakat. ${ }^{2}$

Berdasarkan uraian dari latar belakang, maka penulis tertarik untuk menelakukan penelitian dengan judul "Efektifitas Arang Sekam Padi Dalam Menurunkan Kadar Besi (Fe)Pada Air Sumur Bor di Desa Padangloang Kabupaten Pinrang”.

\section{BAHAN DAN METODE}

Penelitian ini merupakan penelitian quasy eksperiment yaitu kegiatan percobaan yang bertujuan melihat pengaruh yang timbul sebagai akibat adanya perlakuan dengan mengakibatkan beberapa faktor pengganggu, dengan rancangan yang di gunakan adalah one group pretest (pengujian Kadar Besi $(\mathrm{Fe})$ sebelum perlakuan) dan post test (pengujian kadar Besi $(\mathrm{Fe})$ setelah perlakuan). Pengambilan sampel air sumur bor yang mengandung besi (Fe) di Dusun Banga Desa Padang Loang Kecamatan Patampanua Kabupaten Pinrang dan percobaan arang sekam padi dilakukan di Unit Pelaksanaan Teknis (UPT) Laboratorium Dinas Lingkungan Hidup Daerah (DLHD) Kota Parepare. Populasi adalah keseluruhan objek penelitian atau objek yang diteliti. Populasi dalam penelitian ini yaitu air sumur bor yang mengandung kadar besi $(\mathrm{Fe})$ di salah satu rumah wargadi Dusun Banga Desa Padangloang Kecamatan Patampanua Kabupaten Pinrang. Sampel adalah sebagian dari keseluruhan objek yang diteliti dan dianggap mewakili sebagian populasi. Sampel dalam penelitian ini yaitu air sumur bor. Adapun teknik pengambilan sampel dalam penelitian ini dilakukan dengan menggunakan metode Grab Sampling yaitu teknik sampling dengan cara mengambil bagian dari satu material (baik di alam maupun dari suatu tumpukan) yang mengandung mineralisasi secara acak (tanpa seleksi yang khusus).

\section{HASIL}

Hasil penelitian eksperimental tersebut menunjukkan arang sekam padi pada konsentrasi 5 gram dapat menurunkan kadar besi $(\mathrm{Fe})$ rata-rata sebanyak 0,72 $\mathrm{mg} / \mathrm{l}$ dengan persentase $39 \%$, pada konsentrasi 10 gram dapat menurunkan kadar besi $(\mathrm{Fe})$ rata-rata sebanyak 1,05 $\mathrm{mg} / \mathrm{l}$ dengan persentase 58\%,pada konsentrasi 15 gram dapat menurunkan kadar besi (Fe) rata-rata sebanyak $1,5 \mathrm{mg} / \mathrm{l}$ dengan persentase $82 \%$. Sehingga peneliti manyatakan bahwa ada penurunan antara efektifitas arang sekam padi dalam menurunkan Kadar Besi $(\mathrm{Fe})$ pada sumur bor dengan menggunakan arang sekam padi dengan berbagai konsentrasi yang berbeda-beda. Dengan kata lain semakin banyak jumlah konsentrasi arang sekam padi yang digunakan maka semakin besar penurunan kadar besi $(\mathrm{Fe})$ air yang terjadi 
pada air sumur bor. Dalam penelitian ini konsentrasi penambahan arang sekam padi yang paling baik digunakan dalam menurunkan Kadar Besi $(\mathrm{Fe})$ pada konsentrasi 15 gram dengan $100 \mathrm{ml}$ air, hasil yang didapatkan $0,30 \mathrm{mg} / \mathrm{l}$. Berdasaran Peraturan Menkes RI No :492/MENKES/PER/IV/2010 tentang persyaratan kualitas air bersih yang menerangkan bahwa kadar besi dalam air maksimum diperbolehkan 1,0 mg/l. ${ }^{4}$

Pada Tabel 4 dapat dilihat perbedaan masing-masing konsentrasi yang menurunkan kadar besi (Fe) pada konsentrasi 5 gram terjadi penuunan kadar besi $(\mathrm{Fe})$ 1,09 mg/l pada konsentrasi 10 gram besi (Fe) $0,76 \mathrm{mg} / \mathrm{l}$ pada konsentrasi 15 gram besi $(\mathrm{Fe}) 0,31 \mathrm{mg} / \mathrm{l}$.

Pada penelitian ini penambahan konsentrasi 5 gram arang sekam padi 100 $\mathrm{ml}$ air belum efektif dalam menurunkan kadar besi (Fe) pada air sumur bor sedangkan pada konsentrasi 15gram arang sekam padi $100 \mathrm{ml}$ air telah efektif dalam menurunkan kadar besi (Fe) hasil yang didapatkan memenuhi syarat baku mutu air bersih yang diperbolehkan.

\section{PEMBAHASAN}

Limbah sekam padi sering diartikan sebagai bahan buangan/bahan sisa dari proses pengolahan hasil pertanian. Proses penghancuran limbah secara alami berlangsung lambat, sehingga limbah tidak saja mengganggu lingkungan sekitarnya tetapi juga mengganggu kesehatan manusia. Pada setiap penggilingan padi akan selalu kita lihat tumpukan bahkan gunungan sekam yang semakin lama semakin tinggi. Saat ini pemanfaatan sekam padi tersebut masih sangat sedikit, sehingga sekam tetap menjadi bahan limbah yang mengganggu lingkungan. ${ }^{5}$

Ditinjau data komposisi kimiawi, sekam mengandung beberapa unsur kimia penting seperti berikut: Kadar air : 9,02\% ,Protein kasar : 3,03\%, Lemak : 1,18\%, Serat kasar : 35,68\%, Abu : 17,17\%, Karbohidrat dasar : 33,71

Komposisi kandungan kimia seperti di atas, sekam dapat dimanfaatkan sebagai arang sekam padi sejenis absorben (penyerap) untuk menurunkan kadar besi (Fe) pada air sumur bor. Pada Tabel 5 dapat dilihat bahwa terjadi penurunan kadar besi $(\mathrm{Fe})$ pada semua konsentrasi, namun pada konsentrasi 15 gram yang efektif untuk menurunkan kadar Besi (Fe) 0,31 $\mathrm{mg} / \mathrm{l}$ dan konsentrasi ini sudah memenuhi syarat.Menurut peraturan mentri kesehatan No. 492/MENKES/PER/IV/2010, yaitu kadar besi $(\mathrm{Fe})$ Memenuhi syarat apabila kadar besi $(\mathrm{Fe})$ berkisar 1,0 mg/liter dan tidak memenuhi syarat apabila kadar Besi $(\mathrm{Fe}) \geq$ $1,0 \mathrm{mg} / \mathrm{liter}$.

Berdasaran Peraturan Menkes RI No :492/MENKES/PER/IV/2010 tentang persyaratan kualitas air bersih yang menerangkan bahwa kadar besi dalam air maksimum diperbolehkan 1,0 mg/l. Dari konsentrasi yang diijinkan oleh peraturan 
kadar besi yang ada pada sumur bor yang dimanfaatkan sebagai air bersih sudah melampaui kadar maksimum yang diperbolehkan yaitu mencapai $1,81 \mathrm{mg} / \mathrm{ll}^{4}$

Hasil penelitian (Jasman, 2011 ) menunjukan penurunan zat besi dengan susunan media saringan yaitu kerikil, ijuk dan arang sekam padi dengan perbandingan antara ketebalan media yaitu $70 \mathrm{~cm}$, paralel dan $80 \mathrm{~cm}$ terjadi penurunan kadar besi yang paling efektif pada ketebalan $80 \mathrm{~cm}$ yaitu $99,52 \% \quad(0,0085$ $\mathrm{mg} / \mathrm{l})$ dan $99,99 \%(0,0001 \mathrm{mg} / \mathrm{l}){ }^{2}$

\section{KESIMPULAN DAN SARAN}

Berdasarkan penelitian yang telah dilakukan maka dapat ditarik kesimpulan bahwa arang sekam padi efektif dalam menurunkan kadar besi $(\mathrm{Fe})$ dengan 100

\section{DAFTAR PUSTAKA}

1. Sunardi, \& Nurliani. 2008. Pemanfaatan Arang Aktif Sekam Padi Dengan

Aktivator Natrium. Jurnal Hutan Tropis

Borneo no. 22 , 99-104. [diakses pada 06

Maret 2018]

2. Jasman. 2011. Uji Coba Arang Sekam Padi Sebagai Media Filtrasi Dalam Menurunkan Kadar

Fe Pada Air Sumur Bor Di Asrama Jurusan Kesehatan Lingkungan Manado. JKL Volume 1 No. 1 , 49-53.[diakses pada tanggal 02 Februari 2018]

3. Margono, 2010. Buku Saku Pekerja Lapangan. Kridanirmala ml air dengan konsentrasi 15 gram arang sekam padi, dimana semakin banyak jumlah konsentrasi arang sekam padi yang digunakan maka semakin tinggi pula tingkat penurunan Kadar Besi (Fe) yang diturunkan. Oleh karena itu disarankan untuk peneliti selanjutnya karena terbukti terjadi penurunan tiap kontersentrasi maka dapat disarankan untuk membuat suatu produk pengolahan air bersih yang mengandung kadar besi (Fe) yang komersial dan ekonomis. Dan bagi masyarakat yang mempunyai sumber air dengan kadar besi tinggi, khususnya di Dusun Banga Desa Padangloang dapat menggunakan arang sekam padi sebagai alternative pengolahan air bersih umtuk menurunkan kadar besi ( $\mathrm{Fe})$.

Poltekes Kemenkes Surabaya. [diakses pada tanggal 11 Agustus 2018]

4. Peraturan Republik Indonesia. 2010. Peraturan Menteri Kesehatan RI Nomor 492/Menkes/Per/IV/2010 Tentang Persyaratan Kualitas Air Minum. Jakarta. [diakses pada tanggal 02 Februari 2018]

5. Lutfi, M. Dan Efendi, M.R. 2011. Pemanfaatan Limbah Arang Sekam Padi dan Limbah Arang Tempurung Kelapa dalam Proses Penyulingan Air Waduk Pato'an Laok Pamekasan. http://revolusiku89.blogspot.com/201307-25- archive. html. [diakses pada tanggal 16 Februari 2018] 


\section{LAMPIRAN}

Tabel 1. Jumlah penurunan kadar besi (Fe) dengan mengunakan arang sekam padi pada sumur bor di Dusun Banga Desa Padangloang Kecamatan Patampanua Kabupaten Pinrang setelah penambahan arang sekam padi percobaan pertama (pada konsentrasi100 ml)

\begin{tabular}{lcccc}
\hline $\begin{array}{c}\text { Konsentrasi } \\
\text { Arang } \\
\text { Sekam Padi }\end{array}$ & $\begin{array}{c}\text { Hasil Uji Lab } \\
\text { Kadar besi } \\
(\mathrm{Fe})\end{array}$ & $\begin{array}{c}\text { Penurunan } \\
\text { kadar besi } \\
(\mathrm{Fe})\end{array}$ & $\%$ & $\begin{array}{c}\text { Kadar } \\
\text { Maksimum } \\
\text { yang } \\
\text { diperbolehkan }\end{array}$ \\
\hline Kontrol & 1,81 & 0 & 0 & \\
$5 \mathrm{gr}$ & 1,09 & 0,72 & $39 \%$ & $1,0 \mathrm{mg} / 1$ \\
$10 \mathrm{gr}$ & 0,76 & 1.05 & $58 \%$ & \\
$15 \mathrm{gr}$ & 0,30 & 1,51 & $83 \%$ & \\
\hline
\end{tabular}

Tabel 2. Jumlah penurunan Kadar Besi (Fe) dengan mengunakan arang sekam padi pada sumur bor di Dusun Banga Desa Padangloang Kecamatan Patampanua Kabupaten Pinrang setelah penambahan arang sekam padi percobaan kedua (pada konsentrasi $100 \mathrm{ml}$ )

\begin{tabular}{lcccc}
\hline $\begin{array}{c}\text { Konsentrasi } \\
\text { Arang Sekam } \\
\text { Padi }\end{array}$ & $\begin{array}{c}\text { Hasil Uji } \\
\text { Lab } \\
\text { Kadar besi } \\
((\mathrm{Fe})\end{array}$ & $\begin{array}{c}\text { Kadar besi } \\
(\mathrm{Fe})\end{array}$ & $\%$ & $\begin{array}{c}\text { Kadar } \\
\text { Maksimum } \\
\text { yang } \\
\text { diperbolehkan }\end{array}$ \\
\hline Kontrol & 1,81 & 0 & 0 & \\
$5 \mathrm{gr}$ & 1,09 & 0,72 & $39 \%$ & $1,0 \mathrm{mg} / \mathrm{l}$ \\
$10 \mathrm{gr}$ & 0,76 & 1,05 & $58 \%$ & \\
$15 \mathrm{gr}$ & 0,31 & 1,5 & $82 \%$ & \\
\hline
\end{tabular}

Tabel 3. Jumlah penurunan Kadar Besi (Fe) dengan mengunakan Arang sekam padi pada sumur bor di Dusun Banga Desa Padangloang Kecamatan Patampanua Kabupaten Pinrang setelah penambahan arang sekam padi percobaan ketiga (pada konsentrasi $100 \mathrm{ml}$ )

\begin{tabular}{lcccc}
\hline $\begin{array}{c}\text { Konsentrasi } \\
\text { Arang Sekam } \\
\text { Padi }\end{array}$ & $\begin{array}{c}\text { Hasil Uji Lab } \\
\text { Kadar besi( Fe) }\end{array}$ & $\begin{array}{c}\text { Penurunan } \\
\text { kadar besi } \\
(\mathrm{Fe})\end{array}$ & $\%$ & $\begin{array}{c}\text { Kadar } \\
\text { Maksimum } \\
\text { yang } \\
\text { diperbolehkan }\end{array}$ \\
\hline Kontol & 1,81 & 0 & 0 & \\
5 gr & 1,07 & 0,74 & $40 \%$ & $1,0 \mathrm{mg} / 1$ \\
$10 \mathrm{gr}$ & 0,76 & 1,05 & $58 \%$ & \\
$15 \mathrm{gr}$ & 0,31 & 1,5 & $82 \%$ & \\
\hline
\end{tabular}


Tabel 4. Rata-rata jumlah penurunan Kadar Besi $(\mathrm{Fe})$ pada sumur bor dengan menggunakan arang sekam padi di Dusun Banga Desa Padangloang Kecamatan Patampanua Kabupaten Pinrang(pada konsentrasi air $100 \mathrm{ml}$ )

\begin{tabular}{|c|c|c|c|c|c|}
\hline \multirow{2}{*}{$\begin{array}{c}\text { Pengulanga } \\
n\end{array}$} & \multirow{2}{*}{$\begin{array}{l}\text { Kontrol } \\
(0 \text { gr })\end{array}$} & \multicolumn{3}{|c|}{ Arang Sekam Padi } & \multirow{2}{*}{$\begin{array}{c}\text { Kadar } \\
\text { maksimum } \\
\text { yang di } \\
\text { perbolehkan }\end{array}$} \\
\hline & & $5 \mathrm{gr}$ & $10 \mathrm{gr}$ & $15 \mathrm{gr}$ & \\
\hline 1 & 1,81 & 1,09 & 0,76 & 0,30 & \multirow{5}{*}{$1,0 \mathrm{mg} / \mathrm{l}$} \\
\hline 2 & 1,81 & 1,09 & 0,76 & 0,31 & \\
\hline 3 & 1,81 & 1,07 & 0,76 & 0,31 & \\
\hline Jumlah & 5,43 & 3,25 & 2,28 & 0,92 & \\
\hline Rata-rata & 1,81 & 1,09 & 0,76 & 0,31 & \\
\hline
\end{tabular}

Tabel 5. Persentase penurunan Kadar Besi (Fe) setelah penambahan arang sekam padi pada sumur bor di Dusun Banga Desa Padangloang Kecamatan Patampanua Kabupaten Pinrang(pada konsentrasi air $100 \mathrm{ml}$ )

\begin{tabular}{lcccc}
\hline $\begin{array}{c}\text { Konsentrasi } \\
\text { Arang sekam } \\
\text { padi }\end{array}$ & $\begin{array}{c}\text { Rata-rata } \\
\text { kadar besi } \\
(\mathrm{Fe})\end{array}$ & $\begin{array}{c}\text { Penurunan } \\
\text { Kadar besi } \\
(\mathrm{Fe}) \mathrm{mg} / \mathrm{l}\end{array}$ & $\begin{array}{c}\text { Penurunan } \\
\text { kadar besi } \\
(\mathrm{Fe}) \%\end{array}$ & $\begin{array}{c}\text { Kadar } \\
\text { Maksimum } \\
\text { yang } \\
\text { diperbolehkan }\end{array}$ \\
\hline Kontrol & 1,81 & 0 & 0 & \\
$5 \mathrm{gr} / \mathrm{l}$ & 1,09 & 0,72 & $39 \%$ & $1,0 \mathrm{mg} / \mathrm{l}$ \\
$10 \mathrm{gr} / \mathrm{l}$ & 0,76 & 1,05 & $58 \%$ & \\
$15 \mathrm{gr} / \mathrm{l}$ & 0,31 & 1,5 & $82 \%$ & \\
\hline
\end{tabular}

